\title{
The Suitability of Typhoon Disaster Reconstruction Work Planning-A Case of Meizuolyu Stream in Taitung County
}

\author{
Shu-Tzu Chen1, Hung-Ming Shu1, Shin-Yi Dai', Jie-Ming Huang2, Chung-Li Hsu² ${ }^{*}$ \\ ${ }^{1}$ Department of Civil Engineering, National Pingtung University of Science and Tehnology, Pingtung, Chinese Taipei \\ ${ }^{2}$ Department of Soil and Water Conservation, National Pingtung University of Science and Tehnology, Pingtung, \\ Chinese Taipei \\ Email: ${ }^{*}$ clhsu@mail.npust.edu.tw
}

Received 15 August 2014; accepted 22 May 2015; published 25 May 2015

Copyright (C) 2015 by authors and Scientific Research Publishing Inc.

This work is licensed under the Creative Commons Attribution International License (CC BY). http://creativecommons.org/licenses/by/4.0/

(c) (i) Open Access

\begin{abstract}
Due to effects of succession typhoons and heavy rainfall, central government often invests the funds within shortest time of contingency promptly after disaster occurring to handle the planning and design project of taking precautions against natural disaster. Because the time limit of design project operating so generally were planned without many detail investigations, it was necessary to probe into the project effect and reconstruction security behind constructed. In this study, we choose the Meizuolyu stream watershed in Taitung County of eastern Taiwan as the research area to realize the situation and effect of setting up the control work reconstructions by inspecting, surveying and according to hydrology analysis and topography measured, and combined to carry on hydrology mathematical calculations. We adopted HEC-RAS software to make hydrology mathematical calculations, used the result to examine whether the position of each construction was proper, and finally submitted the complete of mend suggestion. The study concluded that no matter how urgent governance was, application of appropriate scientific tools to checklist designed could avoid the mistakes of the generation.
\end{abstract}

\section{Keywords}

Typhoon, Disaster, Reconstruction, Hydrology Analysis

\section{Introduction}

Typhoons of northern hemisphere attack Taiwan several times each year, and always cause severe disasters [1]-

"Corresponding author.

How to cite this paper: Chen, S.-T., Shu, H.-M., Dai, S.-Y., Huang, J.-M. and Hsu, C.-L. (2015) The Suitability of Typhoon Disaster Reconstruction Work Planning-A Case of Meizuolyu Stream in Taitung County. Engineering, 7, 237-247. 
[10]. Under the public pressure and expectation of the local residents, the control work reconstructions and rescue measures must be completed within the shortest period of time after typhoon disasters [11]-[16]. The control work reconstructions should take into consideration preventing the reoccurrence of disasters. However, lacks of overall planning and complete concept due to limited time have led to many repeated or ineffective investments, which cannot control the disasters promptly. Therefore, this study investigated and reviewed the structures of reconstruction and regulation projects, and conducted hydrology mathematical calculation analysis by using one-dimensional hydrology mathematical calculation mode according to the present situations [17]-[22]. Based on the results, suggestions and reinforcement proposals for the existing structures are proposed.

\section{Materials and Methods}

\subsection{Study Area Introduction}

Meizuolyu stream watershed is located beside the Meishan community, north of Chenggong Township, Taitung County. It originates from the south foot of Kaiyan Mt., maximum elevation is $1053 \mathrm{~m}$, the mainstream is 3636 $\mathrm{m}$ long, and the catchment area is 190.33 ha. This stream is a debris flow, oddly numbered Taitung 006 , as shown in Figure 1.

The main geological compositions in this area are Miocene Tuluanshan formation, Pliocene Kangkou limestone, Baliwan formation, Pleistocene to Holocene terrace deposits. Due to the variation of depth of stratum and distribution of various lithofacies, the Tuluanshan formation can be divided into Shimen volcanic breccia and Shihtiping lapilli tuff. Baliwan formation is mainly composed of conglomerate, rhythmic sandstone/shale turbidites and mudstone. The terrace deposits is mainly distributed over coastal marine terrace platforms, the lithologic character is mainly of gravel stratum from the nearshore to beach estuarine facies, sometimes contains sandbed, mud seam, shell and coral fragments and drift wood, as shown in Figure 2.

The soil of this area is composed of the black soils formed by tuff, basic or ultrabasic igneous rock, as well as darkish colluvial soil generated by displacement effects of rolling, sliding or collapse of adjacent soil material, as shown in Figure 3.

The west side of this watershed area is coastal mountain, the east side inclines to the Pacific Ocean, the topography is steep, and the water system is generally of steep slope and rapid current. The landform and topography of the whole area are shown in Table 1. The topography elevation distribution is shown in Figure 4.

From August 4 to 6, 2002, 50 to $100 \mathrm{~mm}$ rainfalls were accumulated in the southwestern region of Taiwan under the influence of peripheral circumfluence of typhoon Kammuri. The maximum rainfall occurred in the non-windward southeast coast on August 5. The rainfall in Chenggong Township of Taitung County was nearly $600 \mathrm{~mm}$ on that day, and the maximum accumulated rainfall exceeded $900 \mathrm{~mm}$, the rainfall hyetograph is shown

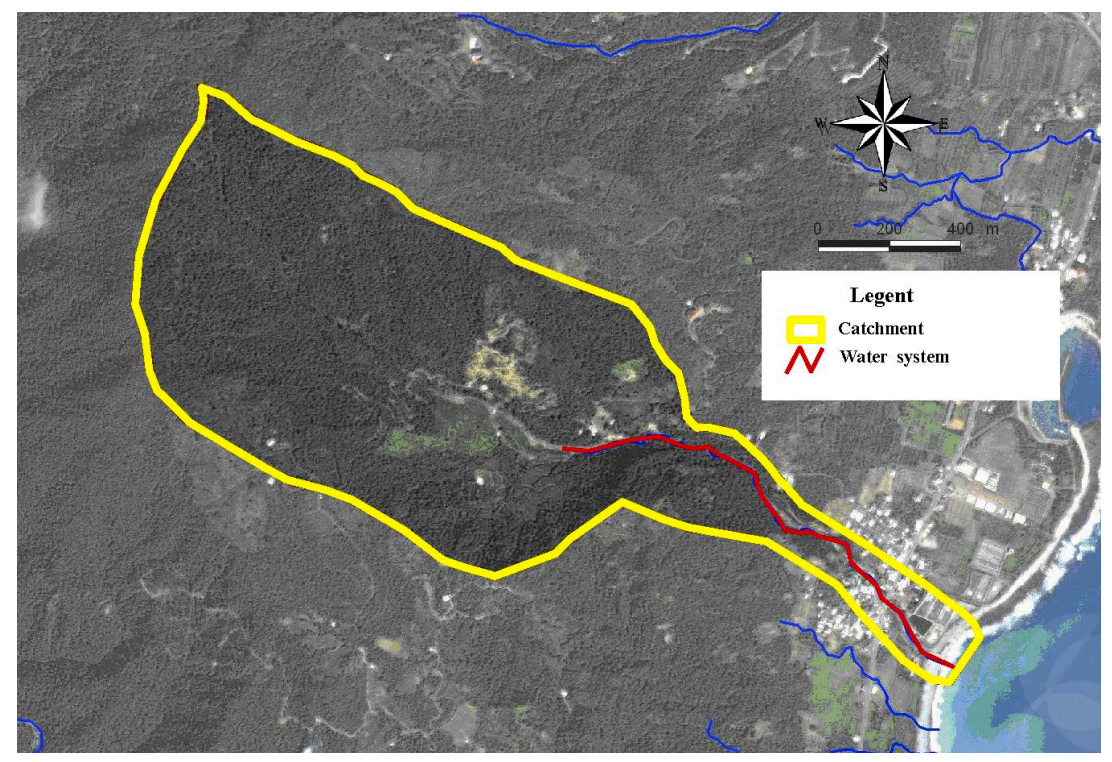

Figure 1. The location of study area watershed. 


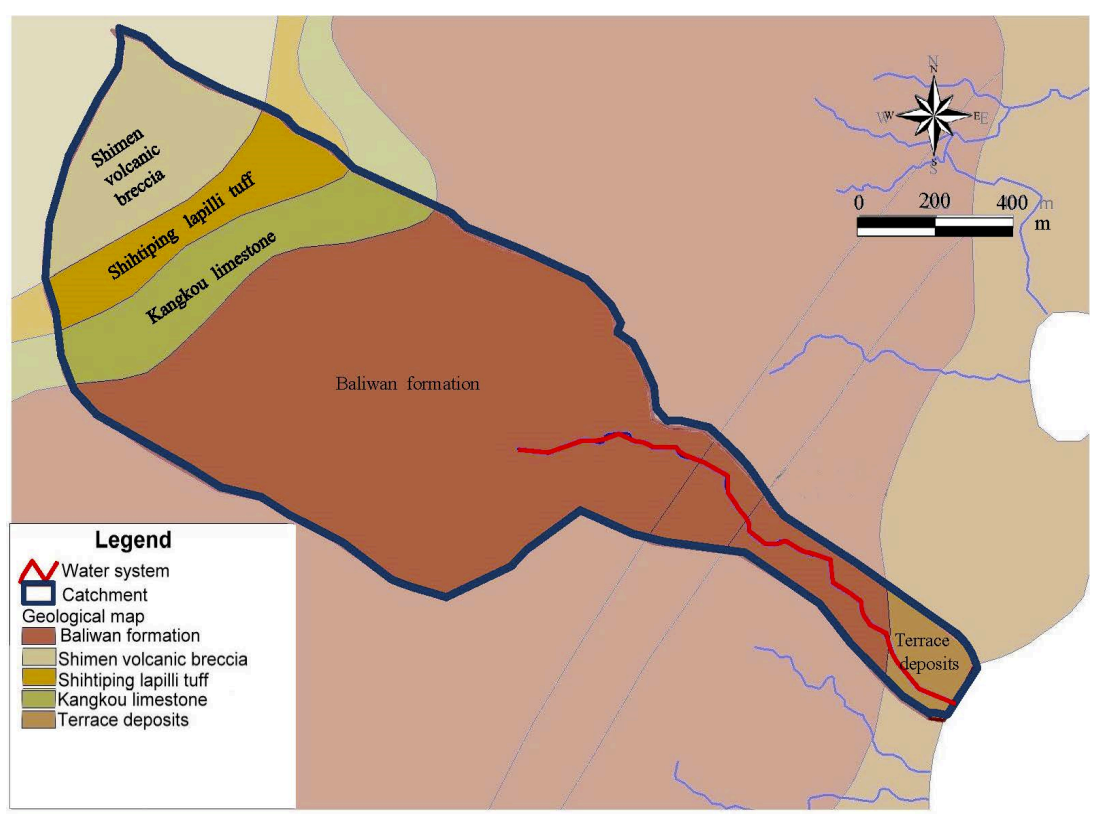

Figure 2. Geological distribution in this study area.

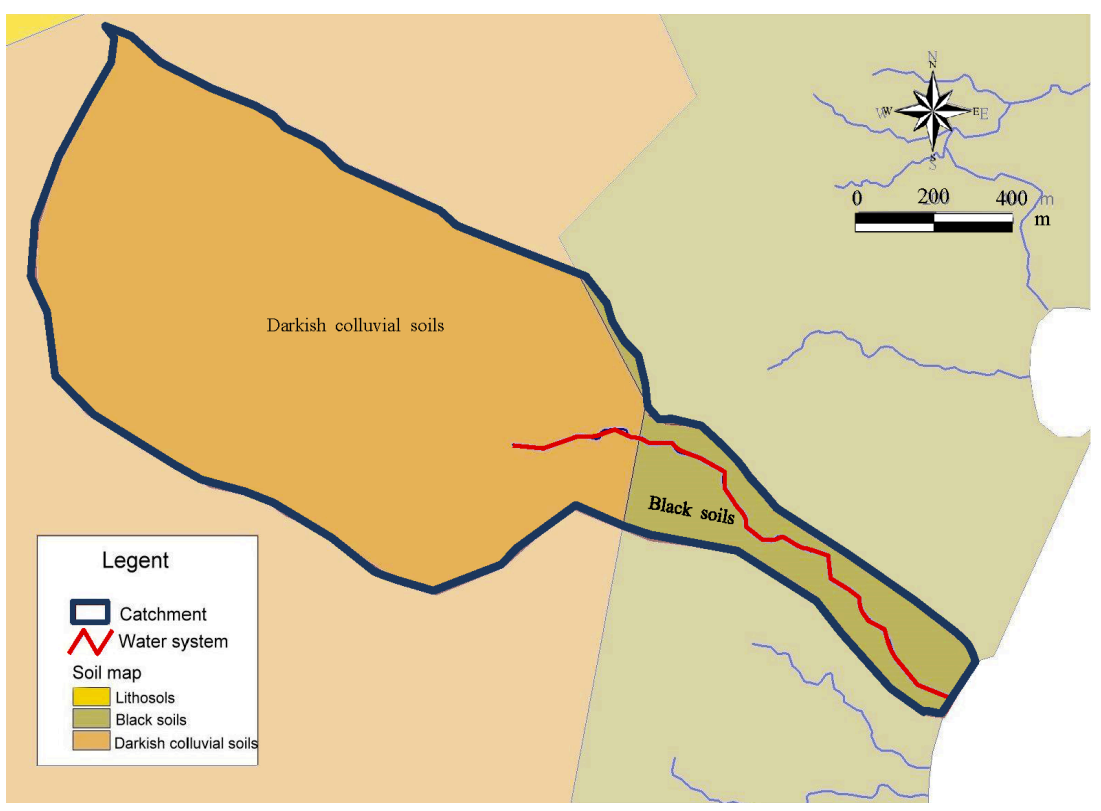

Figure 3. Soil distribution in this study area.

Table 1. Topography distribution in this study area.

\begin{tabular}{ccc}
\hline Elevation $(\mathrm{m})$ & Area $(\mathrm{ha})$ & Percentage $(\%)$ \\
\hline $\mathrm{h} \leq 100$ & 21.28 & 11 \\
$100<\mathrm{h} \leq 200$ & 43.04 & 23 \\
$200<\mathrm{h} \leq 400$ & 79.68 & 42 \\
$400<\mathrm{h}$ & 45.76 & 24 \\
Summary & 189.76 & 100
\end{tabular}




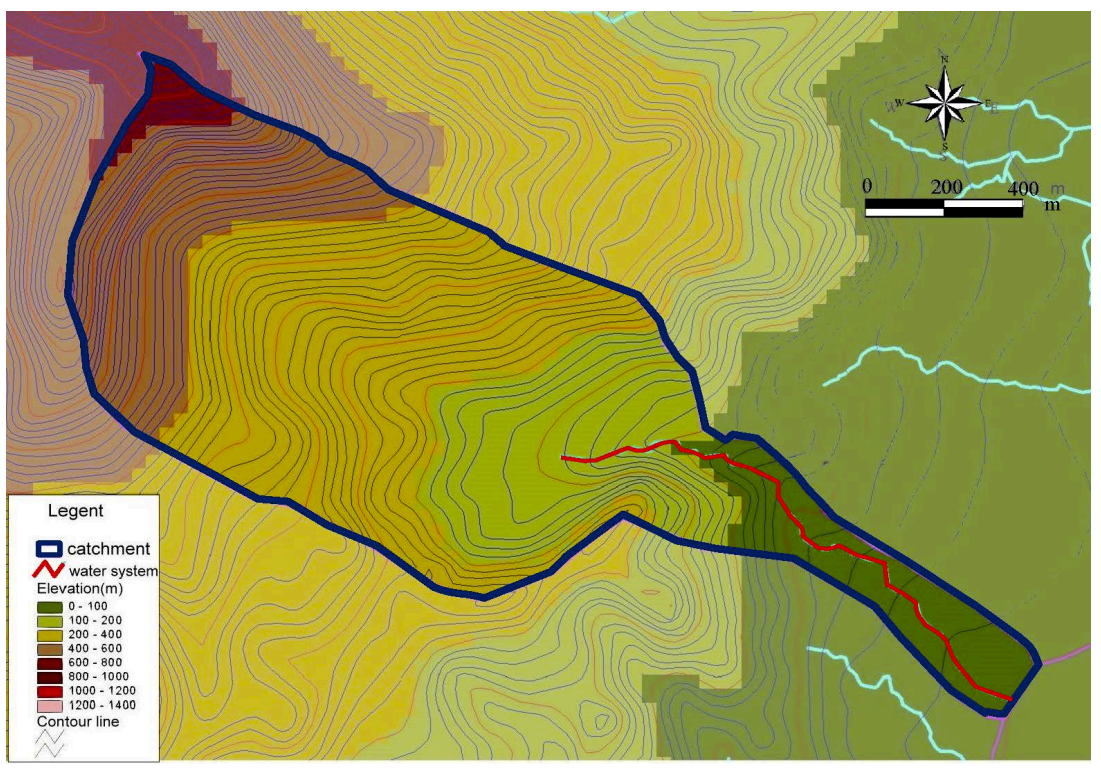

Figure 4. Elevation distribution in this study area.

in Figure 5. The rainfall initiated debris flow that washed off the existing embankment and crashed into Meishan community. The Meizuolyu Bridge was damaged, and many farms were destroyed, as shown in Photo 1. Flood smuggle a large number of sediments and debris into houses. Emergency placement blocks to construct the damaged embankment and prevent flood further inflow villages.

In the aspect of hydrology, the data of weather stations or rainfall stations adjacent to the watershed area of Meizuolyu stream were gathered preliminarily. Five rainfall stations are adjacent to this catchment area, including Chenggong meteorological station and Changbin Rainfall Station of the Central Weather Bureau, Jhongyong Rainfall Station and Jhangyuan (1) Rainfall Station of the Water Resources Agency and Chenggong Rainfall Station of Taitung Irrigation Association. Since this watershed area is very close to Chenggong Meteorological Station, the rainfall record analysis of Chenggong Meteorological Station established by the Central Weather Bureau was adopted. The rainfall data of this station started in 1940, and the average annual rainfall is between $2200 \mathrm{~mm}$ and $2600 \mathrm{~mm}$, the average annual rainfall of past seventy years equivalent Taiwan average number.

The heavy rain brought by the peripheral circumfluence of Typhoon Kammuri in 2002 caused debris flows that washed off the existing embankments and the debris and driftwood crashed into Meishan community, which caused a severe threat to the community. In order to prevent the reoccurrence of disasters, government bureaus carried out a series of overall regulation for this catchment area. Table 2 shows the constructions on Meizuolyu stream after Typhoon Kammuri.

\subsection{River Bed Material Survey}

In the aspect of river bed material survey, the main tasks included river bed material sampling and particle size analysis (e.g. test pit excavation, investigation and sieving analysis) and bed surface particle size diagnosis [23]. Five sampling pits were fixed in Meizuolyu stream watershed as shown in Figure 6. The particle size distribution of field sampling pits is shown in Table 3.

\subsection{Topographic Survey}

The field investigation of this study included topographic survey of reach, midstream and longitudinal profile survey, covering an area of 27.4 ha and length of $2300 \mathrm{~m}$. The results were sorted based on mileage from downstream to upstream.

\subsection{Structural Investigation}

The structural investigation is mainly for the existing structures on the watercourse within the range of survey 


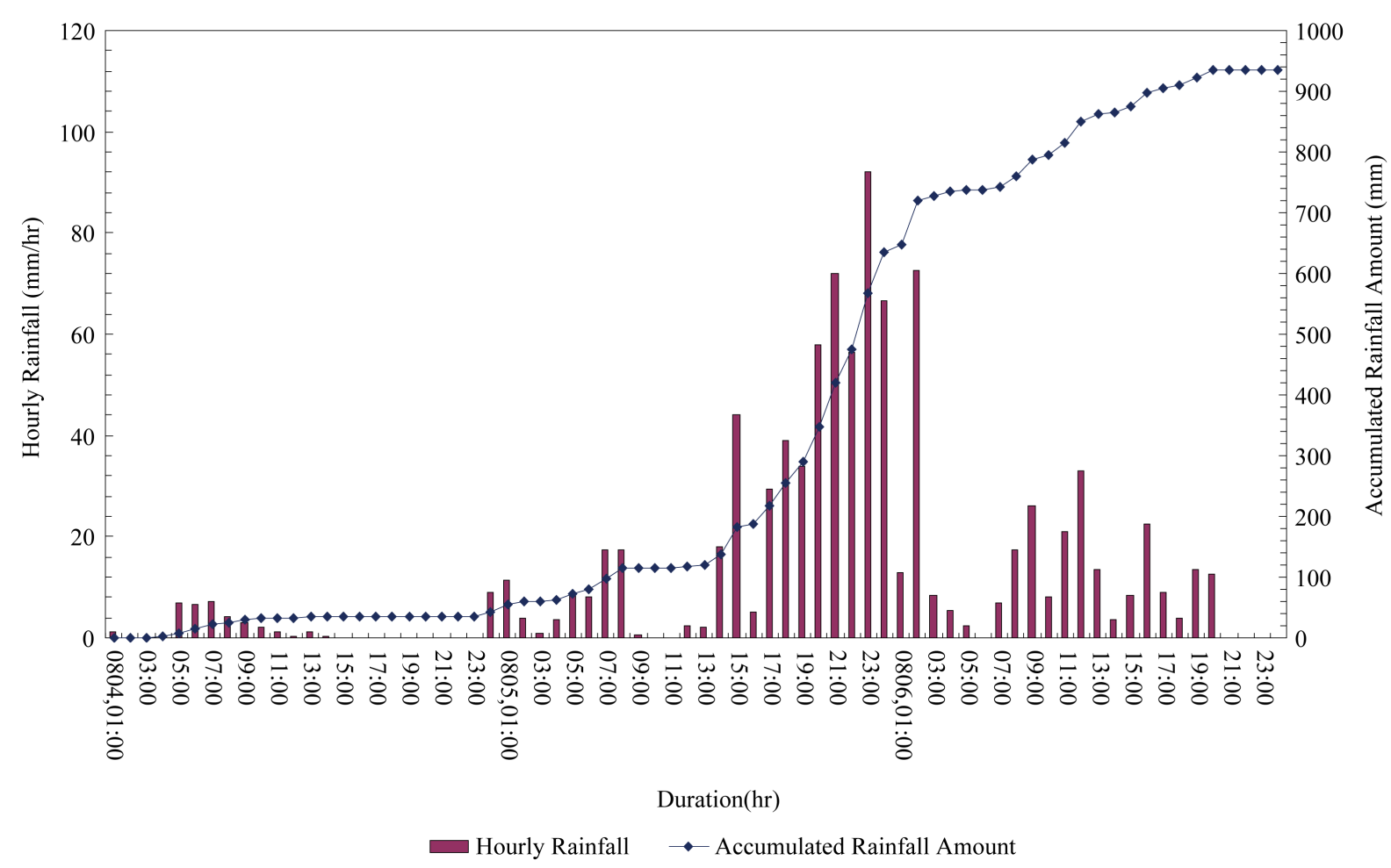

Figure 5. Rainfall hyetograph and accumulated rainfall.
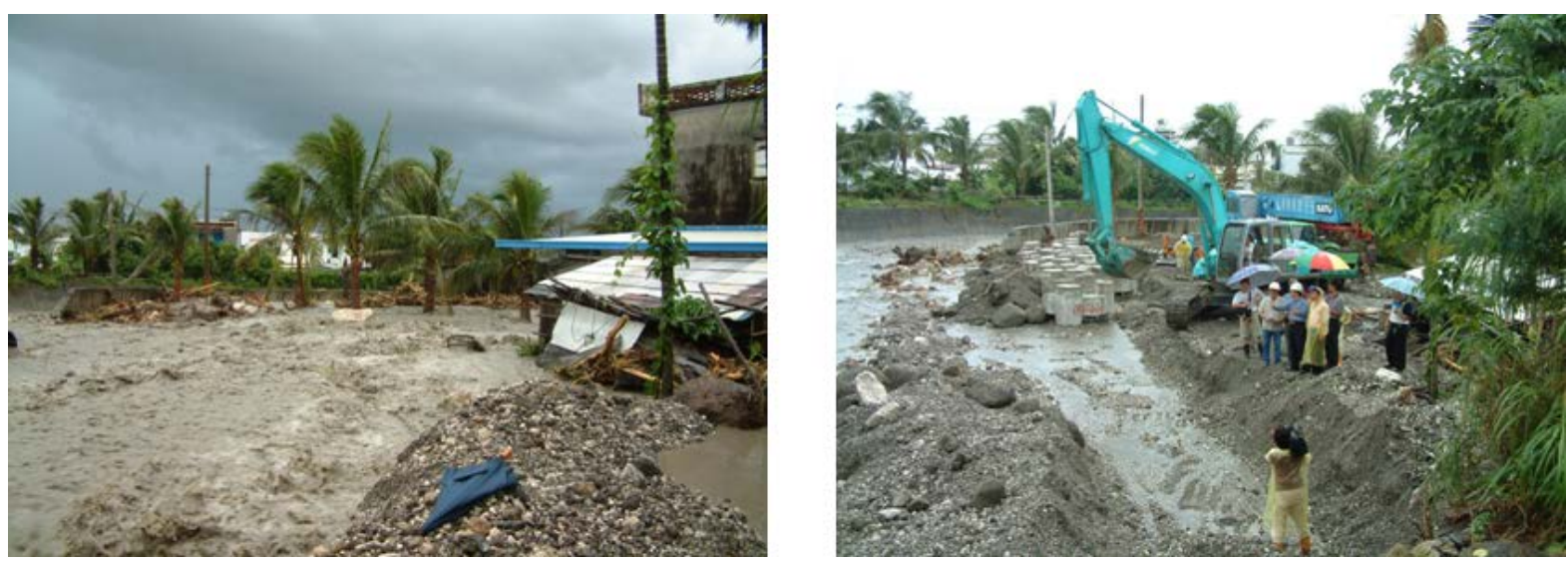

Photo 1. Meizuolyu stream disaster in 2002.

Table 2. Reconstructions after typhoon disaster.

\begin{tabular}{|c|c|c|c|}
\hline Year & Project name & Project contents & Execution unit \\
\hline 2002 & Meizuolyu upstream emergency project & Dolosse breakwater 102 pieces & Chenggung Township Administration \\
\hline 2002 & Meizuolyu upstream regulation project (1) & Stream regulation $200 \mathrm{~m}$ & Soil and Water Conservation Bureau \\
\hline 2003 & Meizuolyu Stream regulation project (2) & Stream regulation $300 \mathrm{~m}$ and revegetation & Soil and Water Conservation Bureau \\
\hline 2004 & Meizuolyu Stream regulation project (3) & $\begin{array}{l}\text { Comb-type dam } 2 \text { Stone masonry } \\
\text { revetment } 60 \mathrm{~m} \text { Ford } 1\end{array}$ & Soil and Water Conservation Bureau \\
\hline 2005 & Meizuolyu Stream regulation project (4) & Submerged dam 2 and revetment $500 \mathrm{~m}$ & Soil and Water Conservation Bureau \\
\hline 2008 & Meizuolyu Stream regulation project (5) & Ground sill 13 and stream regulation $211 \mathrm{~m}$ & Soil and Water Conservation Bureau \\
\hline
\end{tabular}


Table 3. Result of sample pit particle size analysis.

\begin{tabular}{|c|c|c|c|c|c|c|c|c|c|c|}
\hline \multirow{2}{*}{$\begin{array}{l}\text { Sample pit } \\
\text { number }\end{array}$} & \multirow{2}{*}{$\begin{array}{c}\text { Average } \\
\text { particle size }\end{array}$} & \multicolumn{9}{|c|}{ Representative particle size (mm) } \\
\hline & & D10 & D20 & D30 & D35 & D40 & D50 & D65 & D75 & D90 \\
\hline TP-1 & 46.4 & 0.5 & 0.8 & 1.1 & 1.3 & 1.8 & 4.0 & 36.0 & 70.0 & 201.0 \\
\hline TP-2 & 66.8 & 5.0 & 12.0 & 23.0 & 31.0 & 40.0 & 56.0 & 100.0 & 165.0 & 318.0 \\
\hline TP-3 & 54.5 & 2.1 & 5.0 & 20.0 & 23.0 & 31.0 & 50.0 & 90.0 & 112.0 & 315.0 \\
\hline TP-4 & 69.7 & 3.0 & 12.0 & 23.0 & 31.0 & 40.0 & 60.0 & 115.0 & 210.0 & 322.0 \\
\hline ТP-5 & 48.3 & 0.5 & 2.0 & 11.0 & 18.0 & 20.0 & 30.0 & 60.0 & 90.0 & 300.0 \\
\hline
\end{tabular}

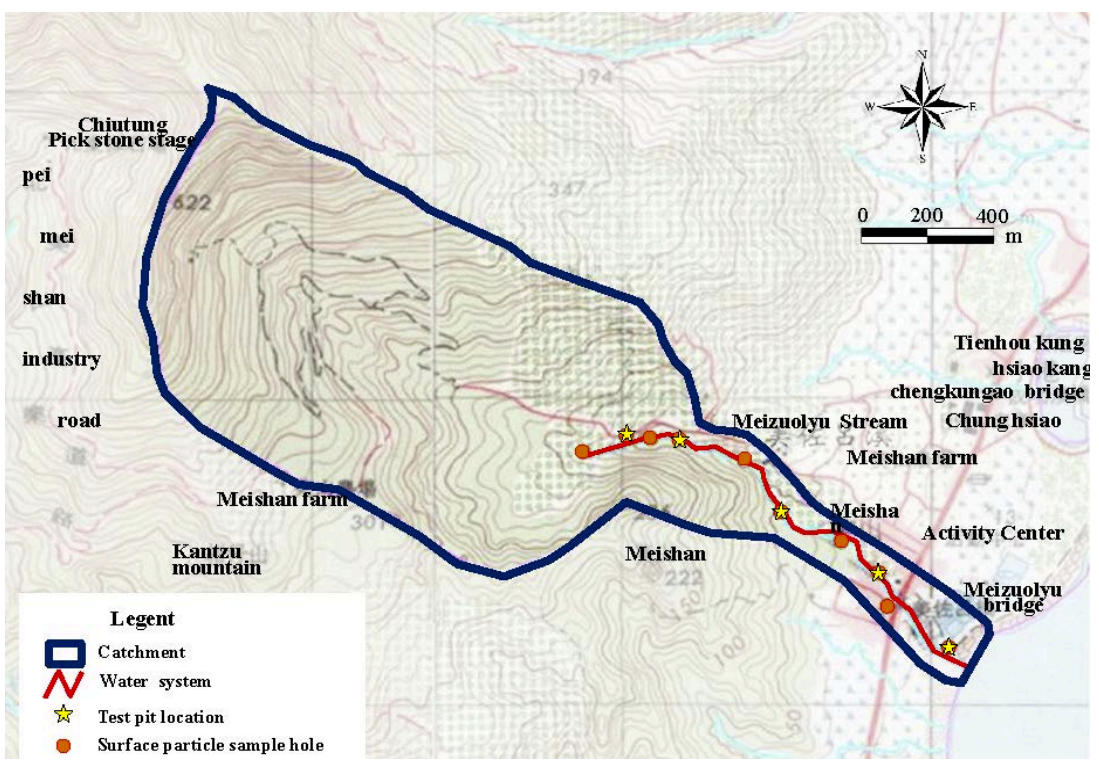

Figure 6. Sample pit and surface particle size survey.

operations. The along-the-line survey method was adopted to move along the river banks toward the upper reach to investigate longitudinal and lateral constructions on the watercourse. The existing circumstances of constructions on the watercourse were recorded. The results are shown in Table 4.

\subsection{Hydraulic Analysis}

This study used the HEC-RAS program developed by the Hydrologic Engineering Center, U.S. Army Corps of Engineers for hydraulic analysis of watercourse. The HEC-RAS mode calculation method mainly uses energy equation and Standard Step Method to figure out the energy equation and the hydraulic situations such as the level of each section and the flow velocity. This mode can process the mixed flow of alternate appearance of hypercritical flow and subcritical flow of rivers in mountain areas. It can also make simple hydraulic analysis of cross-river constructions, as well as analyses and discussions according to the results and the existing circumstances of constructions.

All parameters used in the mode are as follows:

1) Runoff coefficient: 0.9 .

2) Concentration time: the concentration time of the whole catchment area is $0.236 \mathrm{hr}$.

3) The rainfall intensity of 50-year recurrence interval is $143.62 \mathrm{~mm} / \mathrm{hr}$.

4) Peak flow estimation: the peak flow of the whole catchment area is $76.80 \mathrm{cms}$.

5) Manning coefficient: estimated according to the surface particle size analysis of river bed material survey and various empirical formulae, and determined by considering the watercourse landform and surface plantation, and referring to Ven-Te Chow's Manning coefficient [24], as shown in Table 5. 
Table 4. Construction present situation investigation.

\begin{tabular}{ccc}
\hline Stream regulation, revetment construction & Construction & Sedimentation pond \\
\hline $\begin{array}{c}\text { Stream regulation and revetment } \\
\text { construction work well }\end{array}$ & $\begin{array}{c}\text { Comb-type dam, Submerged dam and } \\
\text { Ground sill and work well }\end{array}$ & $\begin{array}{c}\text { Sedimentation pond fill with sand } \\
\text { (volume } 4600 \mathrm{~m}^{3} \text { ) }\end{array}$ \\
\hline
\end{tabular}

Table 5. Estimate riverbed Manning coefficient.

\begin{tabular}{|c|c|c|c|c|c|c|c|c|}
\hline \multirow{3}{*}{ Location } & Einstein & Lane-Carlson & $\begin{array}{c}\text { Mayer and } \\
\text { Peter }\end{array}$ & $\begin{array}{c}\text { San Line } \\
\text { River }\end{array}$ & Strickler & Bray & Huang and $\mathrm{He}$ & \multirow{3}{*}{$\begin{array}{l}\text { Value } \\
\text { chose }\end{array}$} \\
\hline & $0.0132^{*}$ & $0.0156^{*}$ & $0.01216^{*}$ & $0.0162^{*}$ & $0.015^{*}$ & $0.0163^{*}$ & $0.0654^{*}$ & \\
\hline & $\mathrm{D}_{65}^{1 / 6}$ & $\mathrm{D}_{75}^{1 / 6}$ & $\mathrm{D}_{90}^{1 / 6}$ & $\mathrm{D}_{50}^{1 / 6}$ & $\mathrm{D}_{50}^{1 / 6}$ & $\mathrm{D}_{90}^{1 / 6}$ & $\mathrm{D}_{90}^{1 / 6}$ & \\
\hline TP-1 & 0.0163 & 0.0207 & 0.0247 & 0.0234 & 0.0129 & 0.0202 & 0.0326 & $0.035-0.04$ \\
\hline TP-2 & 0.0194 & 0.0239 & 0.0267 & 0.0253 & 0.0200 & 0.0239 & 0.0352 & $0.035-0.04$ \\
\hline TP-3 & 0.0190 & 0.0224 & 0.0267 & 0.0252 & 0.0196 & 0.0235 & 0.0352 & $0.035-0.04$ \\
\hline TP-4 & 0.0198 & 0.0249 & 0.0268 & 0.0253 & 0.0202 & 0.0245 & 0.0353 & $0.035-0.04$ \\
\hline TP-5 & 0.0178 & 0.0216 & 0.0264 & 0.0250 & 0.0180 & 0.0220 & 0.0349 & $0.035-0.04$ \\
\hline
\end{tabular}

6) Boundary condition: this project adopts the mixed flow algorithm to calculate the condition of boundary: the upstream uses the normal depth as the initial level for counting; the downstream uses the critical depth of each recurrence interval as the initial level for counting.

\section{Results and Discussion}

\subsection{Flood Capacity Examination}

Comb-type dam, submerged dam, ground sill and stream regulation were constructed on the upper reach and lower reach of this stream. The result of hydrologic analysis is shown in Figure 7. According to the analysis of various profiles, at right bank of $0 \mathrm{k}+100$ is sustainable to only 10 -year recurrence interval flood peak, this part is located in the lower reach of Meizuolyu bridge. There would be no influence on the highways and settlements, protective measures are not required. Although at $0 \mathrm{k}+600$ is sustainable to only 5 -year recurrence interval flood peak, both sides are high bottom phases, there is no influence yet, and at $1 \mathrm{k}+299$ reach with steep banks, an over 25 -year recurrence interval flood peak may overflow the flood land. Only this flood land has no protected object, the reaches other than the above ones can sustain 50-year recurrence interval flood peak.

\subsection{Debris Flow Analysis}

According to the water and soil conservation manual, the debris flow rate $\left(\mathrm{Q}_{\mathrm{D}}\right)$ can be inferred from the clear water flow rate and the sand volume concentration, namely,

$$
\begin{gathered}
\mathrm{Q}_{\mathrm{D}}=\frac{\mathrm{C}_{*}}{\mathrm{C}_{*}-\mathrm{C}_{\mathrm{D}}} \mathrm{Q}_{\mathrm{w}}=\frac{1}{1-\mathrm{C}_{\mathrm{D}} /\left(1-\mathrm{P}^{\prime}\right)} \mathrm{Q}_{\mathrm{w}} \\
\mathrm{C}_{\mathrm{D}}=\frac{\gamma_{w} \tan \theta}{\left(\gamma_{s}-\gamma_{w}\right)(\tan \varphi-\tan \theta)}
\end{gathered}
$$

where $C_{*}$ : is the sand volume concentration of alluvial soil on stream bed; $C_{D}$ is the sand volume concentration of flowing debris flow (less than $0.9 \mathrm{C}_{*}$, when $\mathrm{C}_{\mathrm{D}}$ is greater than $0.9 \mathrm{C}_{*}$, let $\mathrm{C}_{\mathrm{D}}=0.9 \mathrm{C}_{*}$ ); $\mathrm{QW}$ is the clear water flow rate of simulated flow; $\mathrm{P}^{\prime}=1-\mathrm{C}_{*}$ is the porosity of alluvial soil on stream bed; $\gamma_{W}$ is the clear weight of clear water; $\gamma_{S}$ is the unit weight of earth material; $\theta$ is the river bed gradient; $\varphi$ is the internal friction angle of earth material.

Based on the topographic data of the catchment area, the result of river bed material sampling analysis and the literatures related to debris parameters, assuming that the Meizuolyu stream debris flow occurs in the upper river 


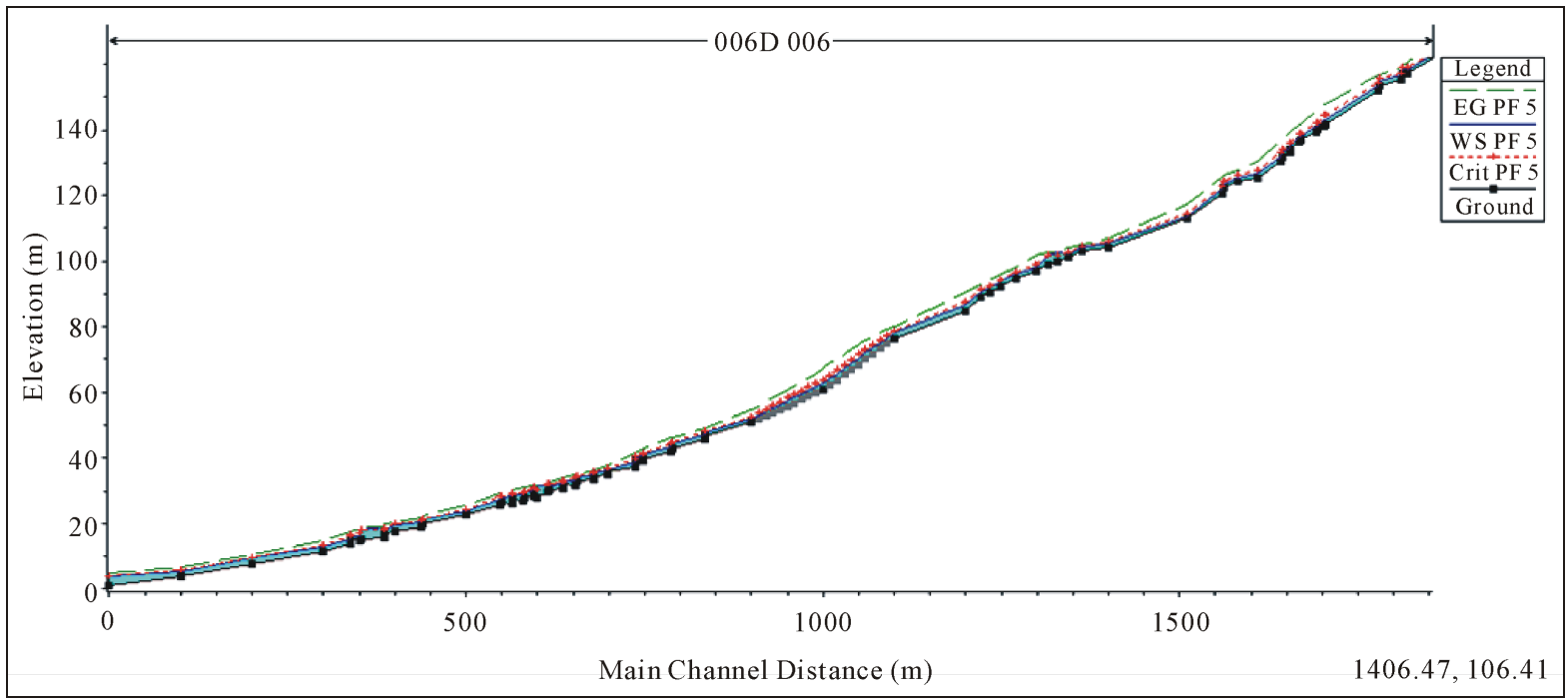

Figure 7. Riverbed longitudinal profile hydrology analysis.

adjacent to the middle course ford. The estimated parameters of debris flow rate of this potential debris flow torrent are shown in Table 6.

The regional roughness can be divided into channel roughness, flood plain area and upper reach woods. According to the Manning coefficient value suggested by the open channel hydraulics and result of field investigation, the Manning coefficient value of watercourse of potential debris flow torrent is set to 0.035 , that of flood plain area is 0.04 , and that of the upper reach woods is 0.08 . The 50 -year recurrence interval debris flow rate is about 1.65 times of clear water flow rate. If the watercourse has no constructions, the stream reflection at the turning of $0 \mathrm{k}+200$ to $0 \mathrm{k}+300$ watercourse would cause debris flows overflow from the right bank to the roads and protected households in the lower reach. A small amount of debris flow overflows from the left bank to the lower reach due to the flood level is higher than the height of bank. The existing stream regulation on the Meizuolyu stream include: comb-type dam and ground sill are set at the upper reach of flooding point; revetments, submerged dam and ground sill are mounted at both sides from the lower reach of flooding point to the Meizuolyu Bridge. Earth material accumulated nearby the comb-type dam in the upper reach of flooding point has reduced the dam's ability to intercept earth material, and the sedimentation pond is full, other constructions are in good condition now.

\subsection{Stream Dredge}

According to the field investigation, none of stream regulation, revetment constructions or lateral construction comb-type dam has obvious failures. Only the slit sabo dam in the upper reach has earth material accumulated nearby which reduces its ability to intercept earth material and the sedimentation pond in the lower reach is silted up. The earth material accumulation nearby the comb-type dam could be dredged properly.

\subsection{Slope Slump}

Typhoon Sepat in August, 2007 caused the collapse of the left road base on the part of main road. Fortunately, there were no houses nearby, only the road was damaged and no casualties. The soil of this area is alluvial soil which is subject to the results of rainfall wash and deposition. The collapsed slopeland has not been restored, if any typhoon or heavy rainfall strikes again, the slopeland may continue to collapse. And if the collapsed debris flows to downstream area, the bridge will destroy and the passage traffic may be influenced.

\subsection{Overflow Area Protection}

According to the field investigation and hydrologic analysis, some areas are likely to be overflowed. Fortunately, there are no houses near the flooding point, so there would be no severe influence. However, based on the profile 
Table 6. Debris flow discharge parameter value.

\begin{tabular}{ccccccc}
\hline Item & $\theta$ & $\gamma_{s}$ & $\phi$ & $\mathrm{C}_{*}$ & $\mathrm{C}_{\mathrm{D}}$ \\
\hline Parameter value & 19.26 & 2.65 & 30 & 0.77 & 0.303 \\
\hline
\end{tabular}

reviewed by the debris flow rate, when the watercourse has no construction, $0 \mathrm{k}+200$ to $0 \mathrm{k}+300$ is the overflow area. This place has many houses; the impact of inconvenience is the same as a disaster. In recently, many projects have been constructed on the Meizuolyu stream, including the slit sabo dam, check dam, ground sill, and revetment constructions, which can prevent stream bed erosion, washing and the downward flowing effect of lots of debris. However, the slit sabo dam in the upper reach has earth material accumulated nearby which reduces its ability to intercept earth material. The sediment deposit pond constructed in 2002 is silted up, sand dredging must be considered. In addition, the joints of constructions in the overflow area must be strengthened to avoid sediment crashing into houses again.

\subsection{Flow Velocity Control}

According to the hydrologic analysis, the slit sabo dam and ground sill lateral constructions in the Meizuolyu stream channel can reduce the profiles with flow velocity exceeding the maximum allowable velocity $6.1 \mathrm{~m} / \mathrm{s}$ greatly, so as to reduce vertical and horizontal washing of stream bed and the caving of revetment footing. Only $0 \mathrm{~K}+300$ to $0 \mathrm{~K}+350$ flow velocity exceeds $6.1 \mathrm{~m} / \mathrm{sec}$, a ground sill is installed at the right side of midstream in this area. Although it can prevent flood erosion, the other side without the ground sill may be degraded by flood and influence the safety of the left revetment base. In addition, $0 \mathrm{~K}+737$ to $0 \mathrm{~K}+789$ flow velocity exceeds $7 \mathrm{~m} /$ $\mathrm{sec}$, this area is a sand storing area, but it is silted up, sand dredging should be considered; $0 \mathrm{~K}+900$ to $1 \mathrm{~K}+300$ flow velocity is fast, some sectors even approach to $10 \mathrm{~m} / \mathrm{sec}$. Since this area is a scouring sector without any construction, continuous ground sills could be considered to fix the bed, and avoid watercourse scouring that may influence the steadiness of the slopes at both sides. $1 \mathrm{~K}+600$ to $1 \mathrm{~K}+800$ sector is constructed with continuous ground sills, but the flow velocity is very fast, it must be paid attention to frequently, so as to avoid the ground sills being damaged that may influence the steadiness of the slopes at both sides.

\section{Conclusions}

On August 5, 2002, the Meizuolyu stream of Taitung County roses suddenly under the impact of peripheral circumfluence of Typhoon Kammuri, Meishan community nearby the Meizuolyu stream was damaged heavily. When a severe typhoon disaster occurs, the government must carry out reconstruction planning and design immediately, so as to avoid the occurrence of another severe disaster. Due to the urgency of project planning, whether the distribution of integrity of planning and the safety of engineering constructions are proper should be reviewed.

According to the longitudinal and lateral profile data obtained by the field survey and the surface particle size analysis of river bed material survey, HEC-RAS was used for hydrology mathematical calculation to review the allocation of all constructions. Based on the preliminary examination, the regulatory works constructed on the Meizuolyu stream could reach the preset goals preliminarily; the engineering of associated works in design could also take the influence of the engineering constructions on the ecology into consideration. However, some areas must be strengthened at present to avoid the recurrence of disasters. Suggestions on the improvement of the constructions in various sectors are giving below. The planning and design principles for future disaster preventing regulation works are also provided for reference.

1) $0 \mathrm{k}+200$ to $0 \mathrm{k}+300$ is the area where the stream water crashes into Meishan community, when the watercourse has no construction. The profile is reviewed according to the debris flow rate. $0 \mathrm{k}+200$ to $0 \mathrm{k}+300$ is actually the overflow area, which has been constructed with regulation works presently, as being limited to use both sides of the land. This area is a bare area; thus, the flow velocity is accelerated. The maintenance of construction works at the stream both sides must be paid attention to frequently, so as to avoid the recurrence of disasters.

2) The sediment deposit pond constructed in regulatory works Phase II is silted up now; the capacity of this area is about $4600 \mathrm{~m}^{3}$. In addition, the slit sabo dam in the upstream area has the ability of sediment material 
accumulated, which can intercept and reduce the sediment material flow to downstream area. The sediment material accumulation in the stream bed could be dredged properly, and a proper dredging could reduce the sand content of debris flow, so as to protect the constructions in the lower reach and guarantee the function of slit sabo dam. Thus, the maintenance of the existing constructions should be considered when planning and designing relevant works.

3) In August 2007, Typhoon Sepat caused the collapse of road base that must be dealt with immediately to avoid the worsening of situation. The watercourse along this road is narrow with steep slopes, and it is not suitable for building stream regulation works. Besides drainage of the pavement, a design of continuous ground sills is the preferred choice for the watercourse, which can avoid the watercourse degrading and bulk excavation of slopes.

4) At the terminal point of this field survey, the upstream area shrinks gradually, the slopes at both sides are exposed, and the watercourse is still accumulated with sediment. According to the distribution diagram of collapsed areas in Taiwan in 2004, this watershed area had only three small collapsed areas, which were distributed in the upstream area, and the total collapsed area was about 0.35 ha, which was about $0.19 \%$ of total area of the catchment area (commissioned by the Geological Survey Institute to the Energy and Environmental Research Institute (ITRI) in 2004). This field survey has not found new collapsed areas, only when additional collapsed areas occur in the catchment area after a typhoon or a heavy rain; the sand generated moves downward to the watercourse that will scour the watercourse of the upstream area which is already narrow and increase the sand shifting downward. Several submerged dams can be built in the upstream to protect the riverbed and avoid watercourse scouring.

In recent years, extreme rainfall events derived from the global climatic variation have occurred frequently. Although the regulatory works constructed for the Meizuolyu stream have reached the preset goal preliminarily, considering the risk management, the software construction should be done besides the hardware construction. The Council of Indigenous Peoples, Executive Yuan, installed a debris flow observation system in the upper reach of this stream in 2003. The field observation apparatuses included 2 sets of infrared breakers, 2 sets of three-axis earth sound sensors, 1 set of video monitoring system, lighting equipments, a field data processor, a system maintenance system, a rainfall counter, an alarm broadcast system, and network transmission equipments. Furthermore, the Soil and Water Conservation Bureau has planned an evacuation route for this community, and stipulated red and yellow threshold values for debris-flow-prone streams. Thus, when a debris flow warning is released, the protected householders must be evacuated to the evacuation shelters through this evacuation route immediately, so as to avoid casualties.

\section{References}

[1] Caine, N. (1980) The Rainfall Intensity-During Control of Shallow Landslides and Dsbris Flows. Geografiska Annaler, 62, 23-27. http://dx.doi.org/10.2307/520449

[2] Takahashi, T. (1981) Debris Flow. Annual Review of Fluid Mechanics, 13, 57-77. http://dx.doi.org/10.1146/annurev.fl.13.010181.000421

[3] Keefer, D.K., Raymond, C.W., Robert, K.M., Earl, E.B., William, M.B., Stephen, D.E., Edwin, L.H., Gerald, F.W., Christopher, S.A. and Robert, S.Z. (1987) Real-Time Landslides Warming during Heavy Rainfall. Science, 238, 921925. http://dx.doi.org/10.1126/science.238.4829.921

[4] Chen, K.S., Wang, J.T. and Mitnik, L.M. (2001) Satellite and Ground Observations of the Evolution of Typhoon Herb near Taiwan. Remote Sensing of Environment, 75, 397-411. http://dx.doi.org/10.1016/S0034-4257(00)00182-6

[5] Cheng, J.D., Lin, L.L. and Lu, H.S. (2002) Influences of Forests on Water Flows from Headwater Watersheds in Taiwan. Forest Ecology and Management, 165, 11-28. http://dx.doi.org/10.1016/S0378-1127(01)00626-0

[6] Yang, C.H. (2008) Flood Control Benefits: A Case Study of the Keelung River Basin. Taiwan Economic Forecast and Policy, 39, 33-67.

[7] Chu, K.H. and Lin, L.L. (2008) Intelligent and Situation-Aware Pervasive System to Support Debris-Flow Disaster Prediction and Alerting in Taiwan. Journal of Network and Computer Applications, 31, 1-18. http://dx.doi.org/10.1016/i.jnca.2006.06.008

[8] Shien, C.L., Chen, Y.S., Tsai, Y.J. and Wu, J.H. (2009) Variability in Rainfall Threshold for Debris Flow after the Chi-Chi Earthquake in Central Taiwan, China. International Journal of Sediment Research, 24, 177-188. http://dx.doi.org/10.1016/S1001-6279(09)60025-1 
[9] Lin, C.W., Chang, W.S., Liu, S.H., Tsai, T.T., Lee, S.P., Tsang, Y.C., Shieh, C.L. and Tseng, C.M. (2011) Landslides Triggered by the 7 August 2009 Typhoon Morakot in Southern Taiwan. Engineering Geology, 123, 3-12. http://dx.doi.org/10.1016/j.enggeo.2011.06.007

[10] Pan, D.G., Tai, J.H., Tsay, C.T. and Yen, T.H. (2013) Climate and Weather Characteristics in Association with the Active Fires in Northern Southeast Asia and Spring Air Pollution in Taiwan During 2010 7-SEAS/Dongsha Experiment. Atmospheric Environment, 78, 35-50. http://dx.doi.org/10.1016/j.atmosenv.2012.12.015

[11] Shieh, J.D. (1999) The Methods of Debris Flow Control Engineering. 2nd Conference on Debris Flow Control Engineering, Hualien, 1999, 328-346.

[12] van Diggelen, R., Grootjans, A.P. and Harris, J.A. (2001) Ecological Restoration: State of the Art or State of Science. Restoration Ecology, 9, 115-118. http://dx.doi.org/10.1046/j.1526-100x.2001.009002115.x

[13] Hsu, C.L., Chou, H.W., Chang, S.N. and Shu, H.M. (2005) The Torrent Control of Yang-Chiu Upstream with Reinforced Concrete Structures Hollow Nest Box in Taitung Count. Journal of Slopeland Hazard Prevention, 4, 19-30.

[14] Hsu, C.L. and Chen, C.I. (2007) The Effects Evaluation of Watershed Sediment Control Stratagem in Taitung Ansowshi Watershed. Journal of Slopeland Hazard Prevention, 6, 45-58.

[15] Ou, R.C. and Lin, L.L. (2007) The Study on Project Management on the Gap of Road Bed Recovery and Re-Construction at Line 124, Route of Peng Lai Village, Nang Zhuang County, Miaoli Hsien. Journal of Slopeland Hazard Prevention, 6, 19-30.

[16] Peng, S.H., Tsai, M.P. and Fan, S.Y. (2011) Environmental Creation and Landscape Planning by Combining Ecological Engineering with the Chingshuigou Creek in Jiji Township, Nantou. Journal of Slopeland Hazard Prevention, 10, 12-24.

[17] Porter, J.W. and McMahon, T.A. (1971) A Model for the Simulation of Streamflow Data from Climatic Records. Journal of Hydrology, 13, 297-324. http://dx.doi.org/10.1016/0022-1694(71)90250-2

[18] Chen, D.T. and Hsu, C.L. (2003) Applied Hydrology and Hydraulic Analysis Methods to Discuss the Mountain Stream Drainage Effect. Journal of Slopeland Hazard Prevention, 2, 93-114.

[19] Hsieh, P.C., Chen, W.F. and Chen, J.T. (2003) Combining HEC-RAS Model with GIS on Flood Simulation for FarTzu Creek. Journal of Soil and Water Conservation, 35, 345-362.

[20] Knebl, M.R., Yang, Z.L., Hutchison, K. and Maidment, D.R. (2005) Regional Scale Flood Modeling Using NEXRAD Rainfall, GIS, and HEC-HMS/RAS: A Case Study for the San Antonio River Basin Summer 2002 Storm Event. Journal of Environmental Management, 75, 325-336. http://dx.doi.org/10.1016/j.jenvman.2004.11.024

[21] Sudhaus, D., Seidel, J., Bürger, K., Dostal, P., Imbery, F., Mayer, H., Glaser, R. and Konold, W. (2008) Discharges of Past Flood Events Based on Historical River Profiles. Hydrology and Earth System Sciences, 12, 1201-1209. http://dx.doi.org/10.5194/hessd-5-323-2008

[22] Sargison, J.E. and Barton, A.F. (2008) Application of HEC RAS to Hydraulic Modelling of an Irrigation Scheme to Determine Potential for Capacity Increase. 9th National Conference on Hydraulics in Water Engineering, Darwin Convention Centre, Darwin, 23-26 September 2008, 73-79.

[23] CSWCS (2005) Soil and Water Conservation Handbook. Chapter 3, Soil and Water Conservation Bureau, Council of Agriculture, Executive Yuan, Taiwan, 24-27.

[24] SWCB (2008) Watershed Management Planning Reference Manual. Chapter 4, Soil and Water Conservation Bureau, Council of Agriculture, Executive Yuan, Taiwan, 4-5. 